\title{
Allometric evidence for the dominant role of surface cells in ammonium metabolism and photo- synthesis in northeastern New Zealand seaweeds
}

\author{
Michael W. Taylor, Richard B. Taylor, T. Alwyn V. Rees* \\ Leigh Marine Laboratory and Schools of Biological and Environmental and Marine Sciences, University of Auckland, \\ PO Box 349, Warkworth, New Zealand
}

\begin{abstract}
Relationships between seaweed morphology and the metabolism of ammonium and carbon were examined for 9 seaweeds from northeastern New Zealand. Maximum rates of surge ammonium uptake and ammonium assimilation, in addition to the maximum ammonium storage pool, were strongly positively correlated with seaweed surface area:volume (SA:V) ratio when expressed per $g$ dry weight, but were largely independent of SA:V ratio when expressed per $\mathrm{cm}^{2}$ surface area. This suggests that ammonium metabolism may be confined largely to the outermost cell layers. Similar scaling properties were found for rates of photosynthesis and, to a lesser extent, respiration. Rates of photosynthesis were similar to those derived from the literature for northern hemisphere seaweeds, while respiration rates were slightly lower among New Zealand seaweeds. These comparatively minor geographic differences suggest that previously documented differences in rates of ammonium uptake between the 2 regions are not related to carbon metabolism. Maximum rates of ammonium assimilation were determined by measuring the internally controlled rate of ammonium uptake, which closely matched the assimilation rate in the green seaweed Ulva sp., the red seaweed Osmundaria colensoi, and the brown seaweed Zonaria turneriana.
\end{abstract}

KEY WORDS: Ammonium assimilation - Seaweeds · Photosynthesis - Scaling · Ammonium storage Respiration. Ammonium uptake Surface area:volume ratio

\section{INTRODUCTION}

Seaweeds are abundant on temperate rocky shores, and are a taxonomically and morphologically diverse group (Lobban \& Harrison 1994). They also exhibit great variability in their ecological and physiological performance, but it is now clear that much of this variability, even across the major divisions, can be accounted for by the functional form of the thallus (Littler \& Littler 1980). Seaweeds take up nutrients and receive light through their surface cells, but possess varying thicknesses of underlying tissue. Some have a thallus only 1 or 2 cells thick (e.g. the sheet-like green alga Ulva lactuca), so that all cells are directly exposed to light and nutrients. Others are many centimetres thick (e.g. the robust kelp Macrocystis pyrifera), so that

\footnotetext{
-Addressee for correspondence.
}

E-mail: ta.rees@auckland.ac.nz the majority of cells are not in contact with the surface. The ratio of seaweed surface area:volume (SA:V) (inversely proportional to mean thallus radius or thickness) has successfully been used as a univariate descriptor of seaweed functional form, accounting for much of the observed variation in mass-specific rates of growth (Nielsen \& Sand-Jensen 1990, Markager \& Sand-Jensen 1994), photosynthesis (Markager \& SandJensen 1994, Enríquez et al. 1995), respiration (Enríquez at al. 1995), and nutrient uptake (Rosenberg \& Ramus 1984, Hein et al. 1995, Taylor et al. 1998). In contrast to mass-specific rates, area-specific rates of ammonium uptake may be largely independent of SA:V ratio (Taylor et al. 1998). This observation is not particularly surprising. It is to be expected that the outer cell layer would be the exclusive site of a vectorial process such as the uptake of a nutrient. Similar arguments would apply to photosynthesis, with most of the incident photons being absorbed by the outermost 
cell layer (but see Ramus 1978). However, for scalar processes, such as ammonium assimilation and respiration, one would expect rates per $\mathrm{cm}^{2}$ to decrease with increasing SA:V ratio.

Seaweed growth is often limited by the availability of nitrogen (Hanisak 1983, Lobban \& Harrison 1994). Ammonium is a major source of nitrogen in seawater, and in marine algae 3 distinct phases of ammonium uptake are evident following addition of the nutrient. These are, in sequence, surge uptake $\left(V_{s}\right)$, internally controlled uptake $\left(V_{\mathrm{i}}\right)$ and externally controlled uptake $\left(V_{\mathrm{e}}\right)$ (Conway et al. 1976). During $V_{\mathrm{s}}$ the uptake rate is maximal at the beginning then steadily declines until it reaches $V_{\mathrm{i}}$, where it remains constant until the nutrient concentration in the medium becomes limiting $\left(V_{e}\right)$ and the uptake rate declines to zero. To date, studies relating ammonium uptake to seaweed SA:V ratio have examined only the surge, or initial, uptake phase. Virtually nothing is known about the relationship, if any, between SA:V ratio and $V_{1}$. The internally controlled phase involves a lower but relatively constant rate of uptake, and is of particular interest given that it is often assumed to represent the rate of ammonium assimilation, the process whereby ammonium is converted into amino acids (Pedersen 1994, McGlathery et al. 1996). Indeed, in the green seaweed Enteromorpha sp. $V_{\mathrm{i}}$ has been shown to equal the maximum rate of assimilation (Rees et al. 1998). There is no a priori reason to assume that $V_{1}$ equals the maximum assimilation rate in all seaweeds. In some species of microalgae, there does not appear to be an internally controlled phase at all (Slawyk et al. 1997). Further information on the role of $V_{i}$ is therefore needed to establish its significance among seaweeds.

The properties of seaweeds that influence storage of ammonium are also poorly understood. Lobban \& Harrison (1994) suggest that mass-specific nitrogen storage capacity is an approximately inverse function of $\mathrm{SA}: \mathrm{V}$ ratio. Indeed, it has been shown that when starved of nitrogen, low SA:V ratio species, such as Gracilaria tikvahiae and Fucus vesiculosus, can sustain growth for longer periods than high $S A$ : $V$ ratio species such as Ulva lactuca and Enteromorpha sp. (Fujita 1985, Pedersen \& Borum 1996). These properties have been related to the seaweeds' 'functional form' (sensu Littler \& Littler 1980), with the implication that opportunistic, high SA:V ratio species have little capacity to store nutrients, relying instead on rapid uptake rates to utilise transient pulses of nitrogen in the environment. Recent evidence, however, suggests that mass-specific storage pools may be larger in some opportunistic species (Pedersen \& Borum 1997), although the relationship between ammonium pools and seaweed SA:V ratio has yet to be examined in detail.
Given the wide range of literature pertaining to ammonium uptake in seaweeds (reviewed by Hanisak 1983, Lobban \& Harrison 1994), it is surprising how little is known about variation in uptake between geographical regions. Recent evidence (Taylor et al. 1998) indicates that ammonium uptake rates for northeastern New Zealand seaweeds are much lower than published values for northern hemisphere (Baltic and east coast of North America) species. While this difference could be due to predominantly diffusive uptake in New Zealand seaweeds (Taylor et al. 1998), it is also possible that other surface-related processes, such as photosynthesis, play an important role. Photosynthesis and nitrogen metabolism are integrally coupled in algae (Turpin et al. 1988, Vergara et al. 1997), with the active uptake and assimilation of ammonium dependent on photogenerated ATP and reductant (Syrett 1981. Turpin 1991). Moreover, the assimilation of ammonium also requires carbon intermediates from the respiratory tricarboxylic acid cycle. The rate of carbon-based processes (photosynthesis and respiration) may therefore be important not only in relation to ammonium uptake, but also to the closely linked assimilation process.

In this paper we demonstrate that the internally controlled rate of ammonium uptake is very similar, or equal, to the maximum rate of assimilation in seaweeds. We then examine the relationship of seaweed $\mathrm{SA}: \mathrm{V}$ ratio to a range of metabolic variables including the uptake, assimilation and storage of ammonium, as well as the carbon-based processes of photosynthesis and respiration. In order to evaluate geographic variability in these parameters, we compare our data for northeastern New Zealand seaweeds with literaturederived values for other regions.

\section{METHODS}

Study site and organisms. The following seaweeds were collected from the intertidal or shallow subtidal at Waterfall Reef, adjacent to the University of Auckland's Leigh Marine Laboratory in northeastern New Zealand (36 $16^{\prime} \mathrm{S}, 174^{\circ} 47^{\prime} \mathrm{E}$ ): Cystophora torulosa (R. Brown) J. Agardh (Phaeophyceae, Fucales), Xiphophora chondrophylla (Turner) Montagne ex Harvey (Phaeophyceae, Fucales), Zonaria turneriana J. Agardh (Phaeophyceae, Dictyotales), Corallina officinalis Linnaeus (Rhodophyceae, Corallinales), Melanthalia abscissa (Turner) Hook. f. et Harvey (Rhodophyceae, Gracilariales), Osmundaria colensoi (Hook, f, et Harvey) R.E. Norris (Rhodophyceae, Ceramiales), Pterocladia capillacea (Gmelin) Bornet et Thuret (Rhodophyceae, Gelidiales), and Enteromorpha sp. (Chlorophyceae, Ulvales). In addition, Ulva sp. (Chlorophyceae, Ulvales) was col- 
lected at a depth of 5 to $10 \mathrm{~m}$ from the Mokohinau Islands, northeastern New Zealand ( $35^{\circ} 55^{\prime} \mathrm{S}, 175^{\circ} 7^{\prime} \mathrm{E}$ ). All collections were made between October 1996 and April 1997. Ammonium concentrations during this period ranged from 0.5 to $2.2 \mu \mathrm{M}$ at Waterfall Reef, and are typically less than $2 \mu \mathrm{M}$ at the Mokohinau Islands (B.C. Dobson unpubl, data).

Experimental conditions. Entire seaweeds were collected the day before an experiment, and preincubated for 12 to $24 \mathrm{~h}$ in flowing seawater under low light $\left(<30 \mu \mathrm{mol}\right.$ photons $\left.\mathrm{m}^{-2} \mathrm{~s}^{-1}\right)$. During experiments, plants were incubated in Perspex chambers containing seawater at $17.5^{\circ} \mathrm{C}$ and illuminated at $150 \mu \mathrm{mol}$ photons $\mathrm{m}^{-2} \mathrm{~s}^{-1}$ (PAR). Fresh weight was recorded at the beginning of an experiment following blotting with paper towels and removal of epiphytic material, while dry weight (DW) was later determined by drying to constant weight at $80^{\circ} \mathrm{C}$. Corallina officinalis samples were treated with $10 \% \mathrm{HCl}$ before drying to remove calcium carbonate. Seaweed surface area was determined by image analysis (Mocha 1.2.10, Jandel Scientific 1994); seaweed volume was determined by displacement of water in a graduated cylinder. Ammonium concentrations in the medium were determined following Koroleff (1983). All experiments in this study were performed a minimum of 3 times.

Direct measurements of rates of ammonium assimilation. For the comparison of rates of assimilation and rates of $V_{1}$, a single species was used from each of the 3 seaweed taxonomic divisions. Rates of ammonium assimilation were determined for Ulva sp., Osmundaria colensoi and Zonaria turneriana during surge uptake using the protonophore carbonyl cyanide $m$ chlorophenylhydrazone (CCCP) (Rees et al. 1998). Ulva sp. tissue ( $5 \mathrm{~g}$ fresh weight) was added to each of 2 chambers containing $400 \mu \mathrm{M}$ ammonium chloride in $250 \mathrm{ml}$ seawater, with 1 chamber also containing $100 \mu \mathrm{M}$ CCCP. The plant in the first chamber, without CCCP, was allowed to take up ammonium for $15 \mathrm{~min}$, at which time CCCP was added to give a concentration of $100 \mu \mathrm{M}$. Preliminary experiments indicated that the release of ammonium trom Ulva $\mathrm{sp}$. reached a stable maximum $140 \mathrm{~min}$ after adding CCCP (data not shown). Water samples were thus removed immediately before addition of the plant, again after the uptake period and finally after the 140 min incubation with CCCP. Total assimilation was calculated as the difference between the cumulative (net) ammonium uptake in the first treatment (i.e. between $t=0$ and $t=$ 155), and net release in the control, when CCCP was added at $t=0$. This procedure was repeated for $O$. colensoi and $Z$. turneriana, except that $6 \mathrm{~g}$ fresh weight of plant tissue was used, with a 60 min uptake period. Also, final samples were taken $360 \mathrm{~min}$ after adding CCCP (i.e. $t=420$ ) for $O$. colensoi, and 540 min later (i.e. $t=600$ ) for $Z$. turneriana, when the release of ammonium was known to have reached a plateau. The addition of CCCP induced the release from $O$. colensoi and $Z$. turneriana of compounds (presumably pigments and secondary metabolites) that interfered with the ammonium assay. Conway microdiffusion units (Syrett 1953) were used to overcome this problem. By combining the sample with $40 \% \mathrm{KOH}$ in the outer chamber of the unit, ammonia gas is liberated from the original sample, and is absorbed by $0.01 \mathrm{~N} \mathrm{H}_{2} \mathrm{SO}_{4}$ in the central chamber.

Measurement of $\boldsymbol{V}_{\mathrm{i}} \cdot V_{\mathrm{i}}$ rate of ammonium uptake was determined for the 9 species using perturbation experiments (Harrison \& Druehl 1982, Harrison et al. 1989), in which the disappearance of nutrients from the medium is followed through time. Rates for Enteromorpha sp., determined using identical experimental conditions, were taken from Rees et al. (1998). Measurements of surge uptake involved all uptake over the initial $60 \mathrm{~min}$, when rates were highest. Plant material was added to seawater containing $400 \mu \mathrm{M}$ ammonium chloride, with approximately 0.5 (UIva sp.), 3 (Corallina officinalis, Osmundaria colensoi, Pterocladia capillacea), 4 (Zonaria turneriana), 8 (Cystophora torulosa, Melanthalia abscissa) or 10 (Xiphophora chondrophylla) g fresh weight plant per litre seawater. Preliminary experiments were run to determine when a particular species entered the internally controlled phase $_{i}$ experiments were generally designed so that at least 4 to $5 \mathrm{~h}$ of this phase were included. To ensure this duration for $V_{1}$, we chose an initial ammonium concentration of $400 \mu \mathrm{M}$; at a lower initial concentration the alga would go directly from surge uptake into the externally-controlled phase (see Pedersen 1994).

Estimation of the maximum ammonium pool size. The maximum ammonium pool size, defined here as the amount of ammonium entering the plant during surge uptake, minus ammonium assimilated over the same time period, was calculated for each species from the results of the perturbation experiments. Because the assimilation rate is the same during surge uptake as during the subsequent $V_{i}$ phase (Rees et al. 1998), the assimilated ammonium may be subtracted from the total uptake. Ammonium stored inside the plant at the start of the experiment was assumed to be negligible. Preliminary experiments indicated that this was largely the case, with ambient ammonium accounting for less than $1 \%$ of the maximum pool size in Ulva sp. and Enteromorpha sp., 12 to $13 \%$ in Osmundaria colensoi and 12 to $18 \%$ in Zonaria turneriana. We could not account for this ammonium in our calculations, as the failure of ammonium release to reach a stable plateau following addition of CCCP meant that ambient pool sizes could not be determined directly for most species. 

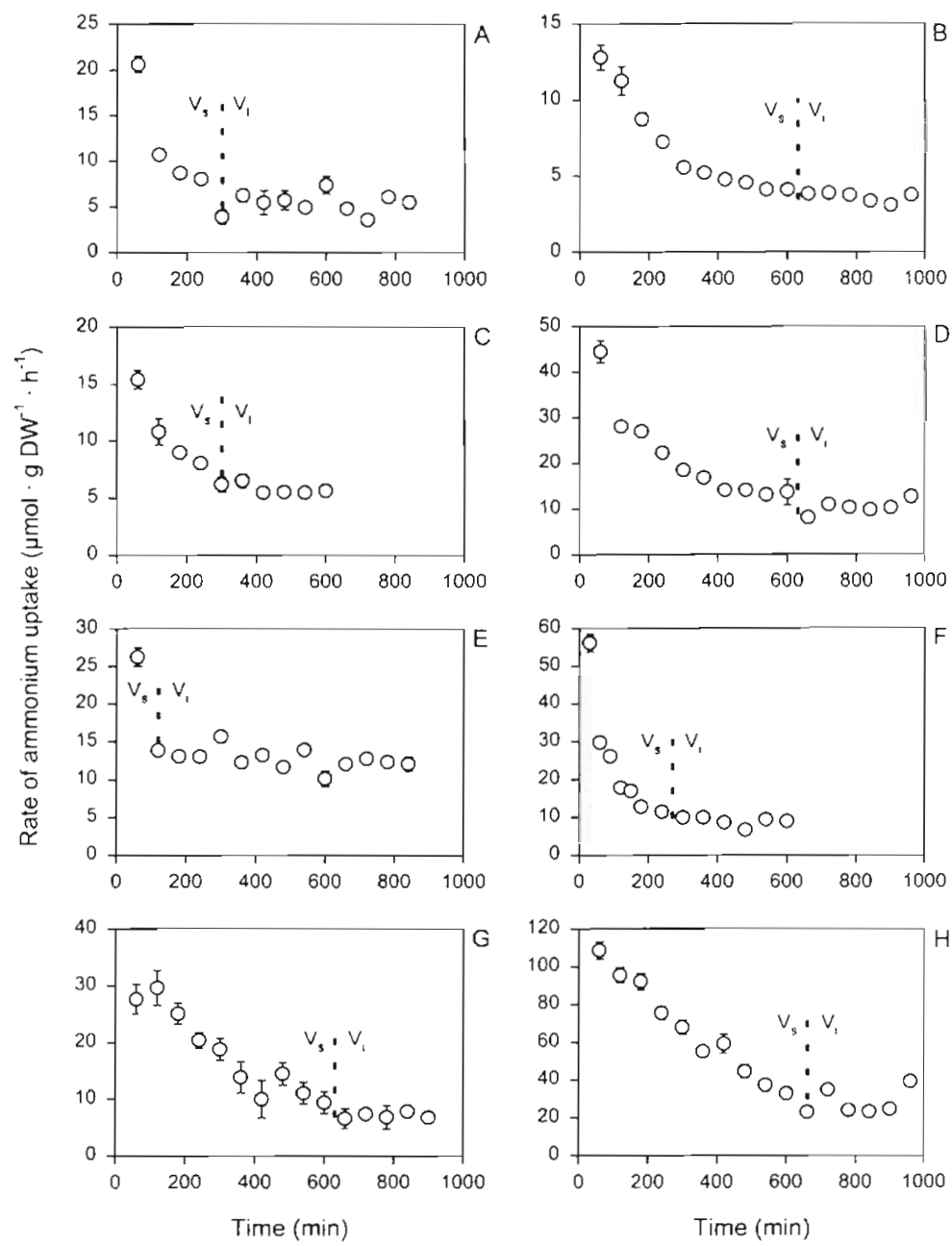

Fig. 1. Changes in rate of ammonium uptake with time for (A) Cystophora torulosa, (B) Xiphophora chondrophylla, (C) Melanthalia abscissa, (D) Osmundaria colensoi, (E) Pterocladia capillacea, (F) Zonaria turneriana, $(G)$ Corallina officinalis and $(H)$ Ulva sp. Values are means \pm 1 SE for at least 3 separate experiments. $V_{s}=$ surge uptake $V_{1}=$ internally controlled uptake

Measurement of photosynthetic and dark respiration rates. Oxygen exchange was measured with an Orion dissolved oxygen meter (Model 840) using approximately $500 \mathrm{ml}$ unenriched seawater in a clear Perspex chamber, with 0.5 (Enteromorpha sp.), 1 (Pterocladia capillacea, Ulva sp.), 1.5 (Corallina officinalis, Zonaria turneriana), 2 (Osmundaria colensol), 3 (Melanthalia abscissa), 8 (Xiphophora chondrophylla) or 15 (Cystophora torulosa) $g$ fresh weight plant. A water jacket surrounding the chamber maintained the experimental medium at $17.5^{\circ} \mathrm{C}$, while illumination was provided by a slide projector. For dark treatments, the entire chamber was wrapped in 2 layers of aluminium foil under 4 layers of black polythene. Vigorous mixing was provided by a magnetic stir bar, placed under a plastic mesh screen at the bottom to avoid damage to the algae. The oxygen electrode was calibrated according to published oxygen solubility data (Riley \& Skirrow 1975).

All experiments involved the use of entire plants, and were performed between 09:00 and $15: 00 \mathrm{~h}$ to minimise diel variation. A photon flux density of $1350 \mu \mathrm{mol} \mathrm{m} \mathrm{m}^{-2} \mathrm{~s}^{-1}$ was sufficient to saturate photosynthesis (authors' unpubl. data), so was used for measurements of maximum photosynthetic rates in most species. Due to photoinhibition at this irradiance, a lower photon flux density $\left(750 \mu \mathrm{mol} \mathrm{m}^{-2} \mathrm{~s}^{-1}\right.$ ) was used for Xiphophora chondrophylla.

To compare these results with those from other regions, we searched the literature for values of maximum rates of photosynthesis and dark respiration. Values reported in carbon units for productivity estimates were converted to equivalent oxygen units ( $\mu \mathrm{mol}$ $\mathrm{O}_{2} \mathrm{~g} \mathrm{DW}^{-1} \mathrm{~h}^{-1}$ ) assuming a photosynthetic quotient (PQ) of 1 (Rosenberg et al. 1995). Although experimental procedures varied widely between published studies, only those experiments performed at between 14 and $21^{\circ} \mathrm{C}$, with carbon content in the medium close to that of ambient seawater (ca $2 \mathrm{mM}$; Bidwell \& McLachlan 1985), were selected. $\mathrm{SA}: \mathrm{V}$ ratios for northern hemisphere species were obtained from Nielsen \& Sand-Jensen (1990) and Hein et al. (1995). These data are available from the authors on request.

Regression analyses. Relationships between metabolic parameters and SA:V ratio were described using linear regression on log-transformed data. Logarithmic transformation was necessary to avoid heteroscedasticity in the regression analyses (Sokal \& Rohlf 1981). Reduced major axis (RMA) regressions were used for all regression analyses, due to experimental error in both variables (Ricker 1973, LaBarbera 1989, Harvey \& Pagel 1991). Analysis of covariance (ANCOVA) was used to test for differences in photosynthetic and respiration rates among regions (with SA:V ratio as the covariate). To express metabolic rates and ammonium pool size per unit surface area, mass-specific (per g DW) values were divided by the SA:DW.

\section{RESULTS}

Rates of ammonium uptake changed substantially with time for all species examined (Fig. 1). Following 
an initial period of rapid uptake (surge uptake phase, ' $V_{\mathrm{s}}$ ' in Fig. 1), which lasted for between 90 (Pterocladia capillacea) and 630 (Xiphophora chondrophylla) min. uptake rates were relatively constant (internally controlled phase, ' $V_{\mathrm{i}}^{\prime}$ in Fig. 1).

Rates of ammonium assimilation during the surge uptake phase (determined using CCCP) were very close to $V_{\mathrm{i}}$ rate in Ulva sp., Osmundaria colensoi and Zonaria turneriana (Table 1); for none of the species were the differences statistically significant (2-tailed $t$ test, $\alpha=0.05$ ).

Rates of surge uptake and internally controlled uptake (hereafter the assimilation rate) both increased with increasing $S A: V$ ratio when expressed relative to biomass (per g DW) (Fig. 2A, Table 2). There was a positive linear relationship between log surge uptake rate and $\log \mathrm{SA}: \mathrm{V}$ ratio (slope $=0.99,95 \% \mathrm{CL}=[0.57$, $1.40]_{i} \mathrm{I}^{2}=0.78$ ), and also between log assimilation rate and $\log \mathrm{SA}: \mathrm{V}$ ratio (slope $=0.90[0.50,1.30] ; \mathrm{r}^{2}=0.76$ ). When expressed relative to thallus surface area (per $\mathrm{cm}^{2}$ ), surge uptake and assimilation rates decreased only slightly with increasing $S A: V$ ratio $\left(r^{2}=0.32\right.$ for surge uptake; $\mathrm{r}^{2}=0.41$ for assimilation) (Fig. 2B, Table 2). The ranges of variation in both uptake and assimilation rates per unit surface area (3.4- and 4.4fold, respectively) were far lower than for the corresponding mass-specific rates (18.8- and 14.8-fold). At starting ammonium concentrations of $400 \mu \mathrm{M}$, assimilation was an approximately constant proportion of surge uptake, irrespective of SA:V ratio. For most species, 25 to $30 \%$ of surge uptake was due to assimilation.

Maximum ammonium pool size increased rapidly with increasing SA:V ratio (slope $=1.25(0.48,2.03$ ); $r^{2}=0.52$ ), but only when expressed relative to biomass (Fig. 3A, Table 2). There was no relationship between $\mathrm{SA}: \mathrm{V}$ ratio and maximum pool size when expressed relative to plant surface area $\left(\mathrm{r}^{2}=0.06\right.$; Fig. 3B, Table 2). The range of variation in pool sizes per unit surface area (11.7-fold) was much lower than for the mass-specific pool sizes (32.9-fold) (Table 2). An outlier

Table 1 Rates of ammonium uptake during internally controlled phase, and assimilation rates during surge uptake, for Ulva sp., Osmundaria colensoi and Zonaria turneriana. Values are means $\pm 1 \mathrm{SE}$, with number of separate experiments given in parentheses

\begin{tabular}{|lcc|}
\hline Species & $\begin{array}{c}\text { Internally controlled } \\
\text { uptake rate } \\
\left(\mu \mathrm{mol} \mathrm{g} \mathrm{DW}^{-1} \mathrm{~h}^{-1}\right)\end{array}$ & $\begin{array}{c}\text { Assimilation rate during } \\
\text { surge uptake } \\
\left(\mu \mathrm{mol} \mathrm{gW}^{-1} \mathrm{~h}^{-1}\right)\end{array}$ \\
\hline Ulvasp. & $29.4 \pm 1.1(5)$ & $21.8 \pm 2.9(5)$ \\
O. colensoi & $11.3 \pm 0.5(7)$ & $8.7 \pm 2.8(4)$ \\
Z. turneriana & $9.0 \pm 0.4(8)$ & $7.9 \pm 2.1(4)$ \\
\hline
\end{tabular}
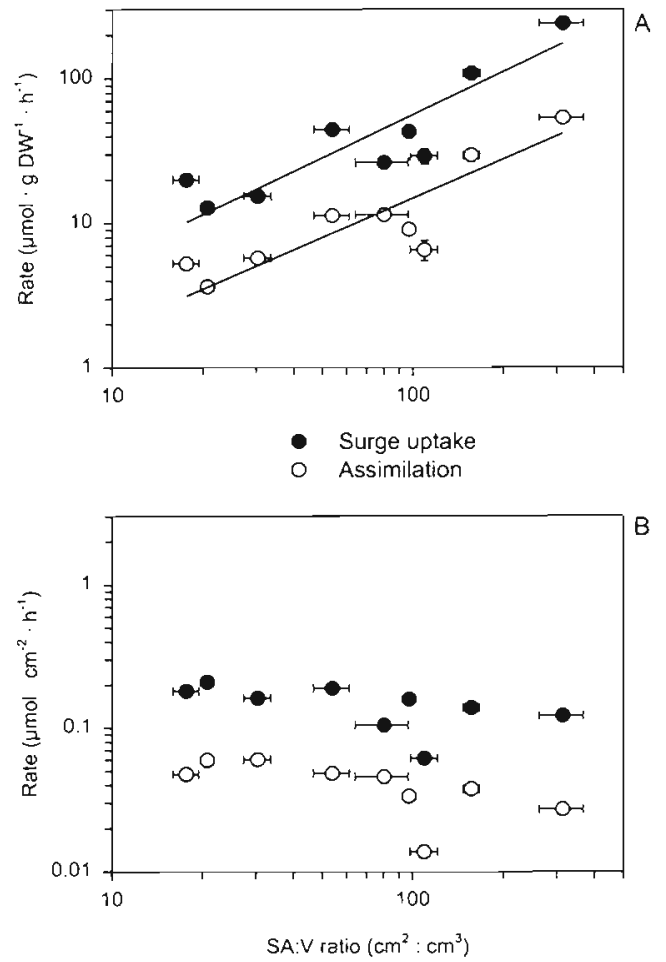

Fig. 2. Rates of surge uptake and assimilation of ammonium versus SA:V ratio for 9 seaweeds from northeastern New Zealand, expressed on a (A) per unit biomass ( $g$ DW) and (B) per unit surface area $\left(\mathrm{cm}^{2}\right)$ basis. Values are means $\pm 1 \mathrm{SE}$

was Pterocladia capillacea, which had a pool size some 5 to 8 times smaller than other seaweeds with similar $\mathrm{SA}: \mathrm{V}$ ratios. Removal of $P$. capillacea from the analysis resulted in a decrease in the range of variation in pool sizes relative to both surface area (3.3-fold) and mass (17.9-fold); the coefficient of determination $\left(r^{2}\right)$ increased to 0.11 and 0.81 for area- and mass-specific rates, respectively.

Maximum rates of photosynthesis, when normalised to biomass, increased with increasing SA:V ratio (slope $\left.=0.89(0.53,1.25) ; r^{2}=0.80\right)$, as did rates of dark respiration (slope $\left.=0.63[0.34,0.92] ; r^{2}=0.74\right)$ (Fig. 4A, Table 2). Photosynthetic rates per unit surface area were relatively constant $\left(r^{2}=0.40\right)$ (Fig. $4 \mathrm{~B}$, Table 2), although Enteromorphasp. (SA:V ratio $=315 \mathrm{~cm}^{2}: \mathrm{cm}^{3}$ ) had very low rates of both photosynthesis and dark respiration compared with the other species. Photosynthetic rates per unit surface area varied 5.0 -fold, with a 14.8 -fold variation in rates per unit biomass (Table 2 ). The range of variation in rates of dark respiration per unit surface area (7.8-fold) was similar to the range for mass-specific rates (6.6-fold) (Table 2).

Maximum photosynthetic rates were very similar for seaweeds from northeastern New Zealand and from the northern hemisphere (Fig. 5A). Rates of dark respi- 

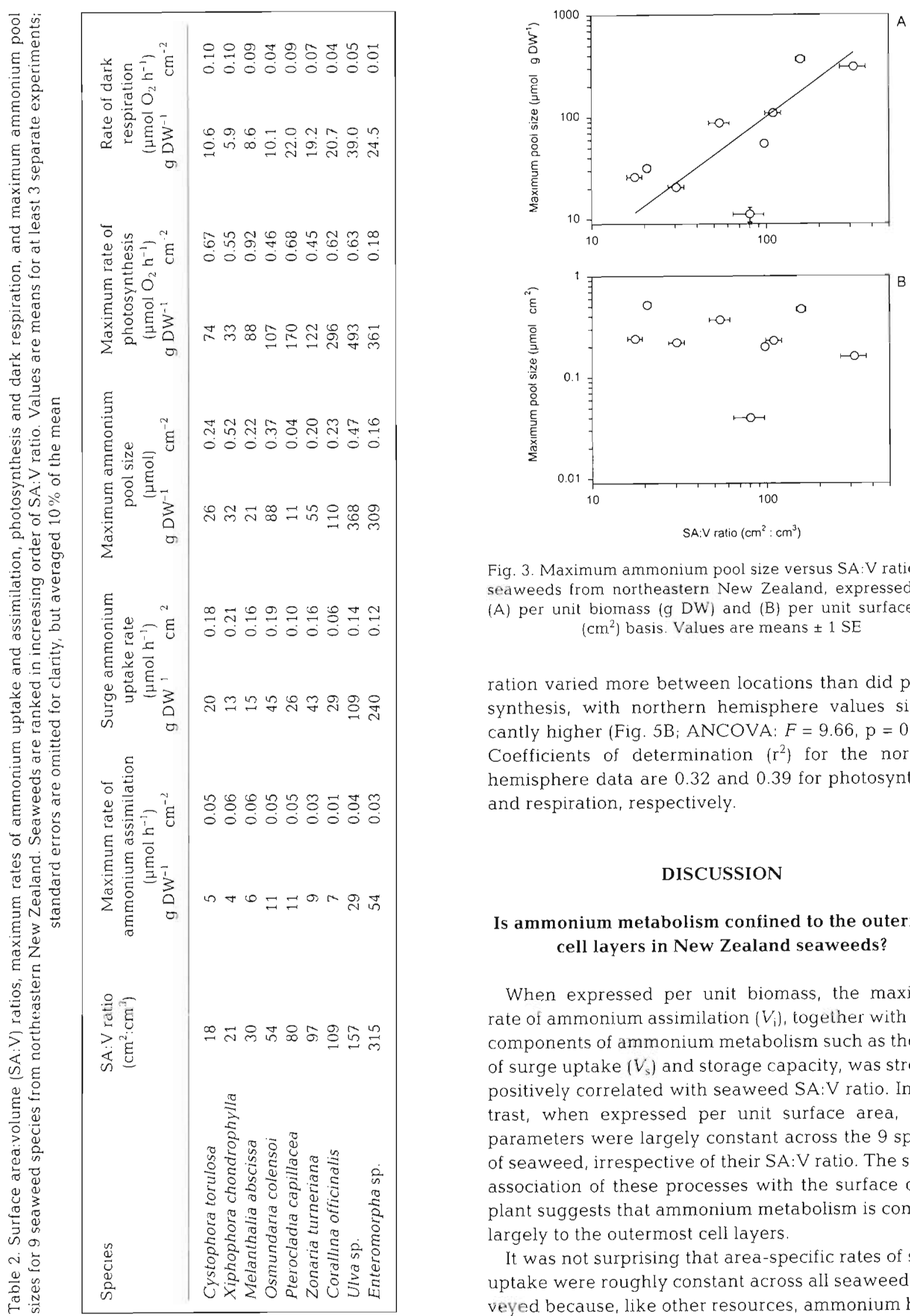

Fig. 3. Maximum ammonium pool size versus SA:V ratio for 9 seaweeds from northeastern New Zealand, expressed on a (A) per unit biomass (g DW) and (B) per unit surface area $\left(\mathrm{cm}^{2}\right)$ basis. Values are means $\pm 1 \mathrm{SE}$

ration varied more between locations than did photosynthesis, with northern hemisphere values significantly higher (Fig. 5B; ANCOVA: $F=9.66, p=0.009$ ) Coefficients of determination $\left(\mathrm{r}^{2}\right)$ for the northern hemisphere data are 0.32 and 0.39 for photosynthesis and respiration, respectively.

\section{DISCUSSION}

\section{Is ammonium metabolism confined to the outermost cell layers in New Zealand seaweeds?}

When expressed per unit biomass, the maximum rate of ammonium assimilation $\left(V_{i}\right)$, together with other components of ammonium metabolism such as the rate of surge uptake $\left(V_{\mathrm{s}}\right)$ and storage capacity, was strongly positively correlated with seaweed $\mathrm{SA}: \mathrm{V}$ ratio. In contrast, when expressed per unit surface area, these parameters were largely constant across the 9 species of seaweed, irrespective of their SA:V ratio. The strong association of these processes with the surface of the plant suggests that ammonium metabolism is confined largely to the outermost cell layers

It was not surprising that area-specific rates of surge uptake were roughly constant across all seaweeds surveyed because, like other resources, ammonium has to 


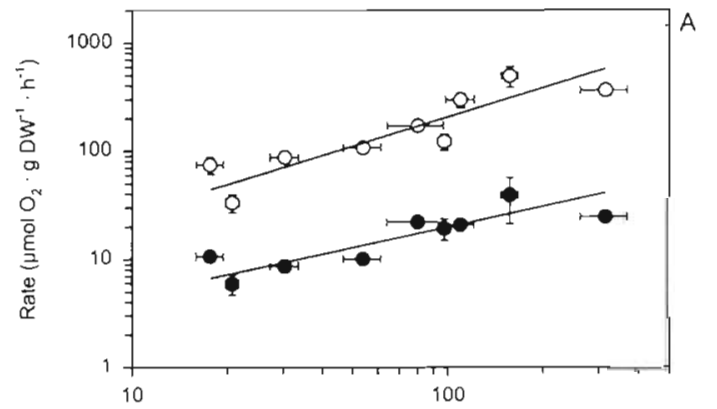

- Maximum photosynthesis (net)

- Dark respiration

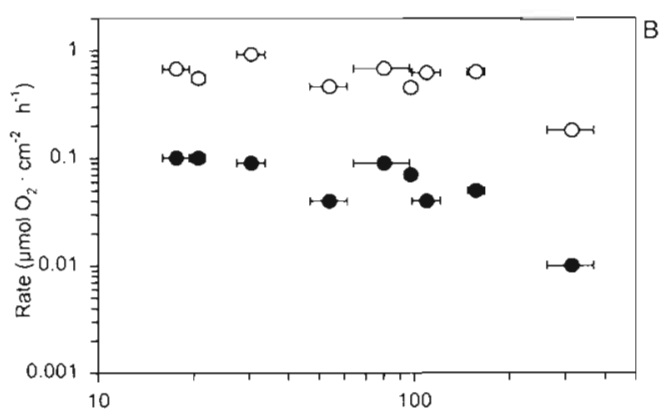

SA:V ratio $\left(\mathrm{cm}^{2} \mathrm{~cm}^{3}\right)$

Fig. 4. Rates of maximum net photosynthesis and dark respiration versus $\mathrm{SA}: \mathrm{V}$ ratio for 9 seaweeds from northeastern New Zealand, expressed on a (A) per unit biomass (g DW) and (B) per unit surface area $\left(\mathrm{cm}^{2}\right)$ basis. Values are means $\pm 1 \mathrm{SE}$

be transported across the plant surface (Carpenter 1990, Hein et al. 1995). However, rates of assimilation also showed the same pattern, which is more interesting since assimilation need not in principle be limited to the outermost cells. A possible explanation is that glutamine synthetase (GS), the primary ammonium assimilatory enzyme, may be confined to the outer layers of the plant. Two isoforms of GS exist in plants, one of which $\left(\mathrm{GS}_{2}\right)$ is located in the chloroplast (Lea et al. 1990). If $\mathrm{GS}_{2}$ is the isoform involved in primary nitrogen assimilation (Oliveira et al. 1997), then this could explain the association of ammonium assimilation with the outer, photosynthetic cells. This explanation is particularly compelling given the strong coupling between ammonium assimilation and carbon metabolism in algae (Turpin 1991, Vergara et al. 1997).

In contrast to New Zealand seaweeds, there appears to be little influence of $\mathrm{SA}: \mathrm{V}$ ratio on rates of ammonium assimilation in many northern hemisphere species. Maximum assimilation rates for 6 Danish seaweeds varied little with thallus morphology, increasing only slightly with increasing SA:V ratio (Pedersen \& Borum 1997). Rates were generally slightly higher than those in this study. Additionally, a seaweed from eastern USA, Gracilariopsis lemaneiformis, with a SA:V ratio of approximately $100 \mathrm{~cm}^{2}: \mathrm{cm}^{3}$, exhibited a very high assimilation rate of $60 \mu \mathrm{mol} \mathrm{g} \mathrm{DW}^{-1} \mathrm{~h}^{-1}$ at an ammonium concentration of $200 \mu \mathrm{M}$, with no evidence of saturation (Vergara et al. 1995). It should be noted, however, that the temperature used for the $G$. lemaneiformis experiments was some $10.5^{\circ} \mathrm{C}$ higher than used in the present study. As ammonium assimilation is an enzymatic process, we would expect an increase in rates at higher temperatures. A more extensive investigation of assimilation rates is needed to establish the existence (or otherwise) of a consistent location effect. We were unable to locate sufficient assimilation data to justify plotting them against our values.

Rates of ammonium uptake were initially much greater than rates of assimilation, so ammonium that is not immediately assimilated must be diverted to internal pools for storage. The calculated maximum ammonium pool was largely independent of SA:V ratio when normalised to surface area. This suggests that, as for
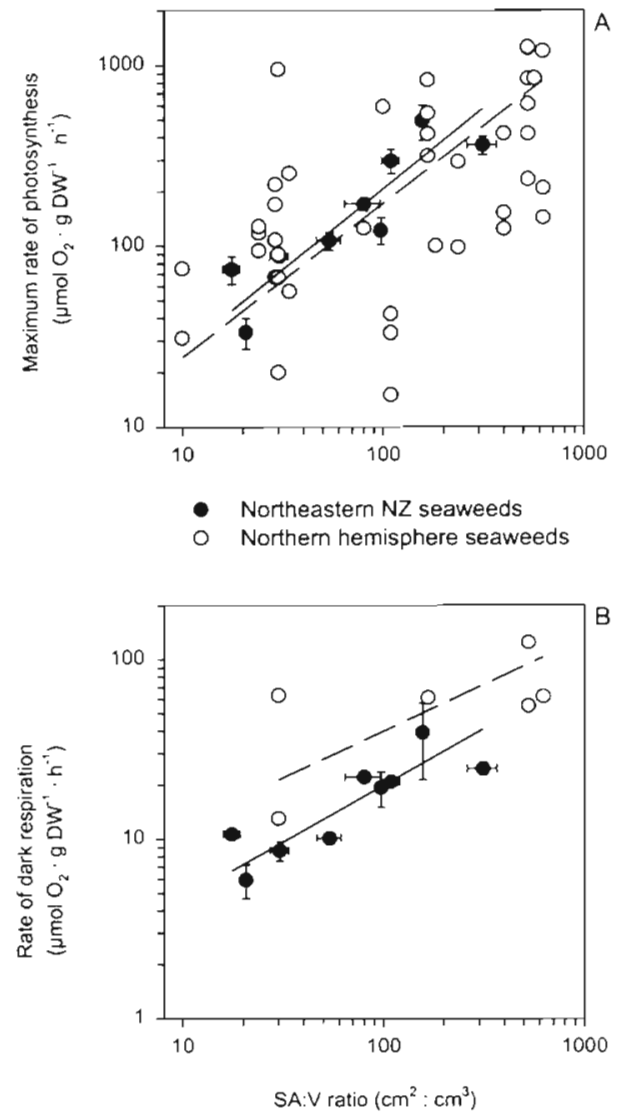

Fig. 5. Rates of (A) maximum net photosynthesis and (B) dark respiration for seaweeds from northeastern New Zealand $(\bullet,-)$ and from the northern hemisphere $(0,--)$ 
surge uptake and assimilation, storage of ammonium occurs predominantly in the outer cell layers. Transverse profiles of tissue composition revealed a similar phenomenon in the kelp Laminaria (Kremer 1980). In 3 species of Laminaria, 67 to $70 \%$ of total cellular nitrogen is present in the meristodermal (outer) tissue, despite the meristoderm comprising only 2 to $6 \%$ of total biomass (Kremer 1980). Soluble nitrogen (which would include ammonium) is similarly concentrated in the outer tissue, with 44 to $60 \%$ present in the outer 4 to $6 \%$ of tissue. Ammonium pools in 6 Danish seaweeds were generally much smaller than those of New Zealand seaweeds, with only a slight positive influence of SA:V ratio (Pedersen \& Borum 1997). In contrast. ammonium pools in the North American seaweed Gracilariopsis lemaneiformis were of similar size to those in New Zealand seaweeds with similar SA:V ratios (Vergara et al. 1995).

The scaling of maximum ammonium pool size to $S A: V$ ratio indicates that, for a given biomass, high SA:V ratio seaweeds such as Enteromorpha sp. will have a greater capacity to accumulate ammonium than thicker, low SA:V ratio species such as Cystophora torulosa. It is likely, however, that the higher growth rates associated with higher $\mathrm{SA}: \mathrm{V}$ ratios result in a more rapid depletion of these pools (Pedersen \& Borum 1996). Indeed, Pedersen \& Borum (1996) found that positive growth in the low SA:V ratio Fucus vesiculosus continued for $46 \mathrm{~d}$ following saturation of internal nitrogen pools, compared with only $9 \mathrm{~d}$ in the high SA:V ratio Ulva lactuca. This is despite the mass-specific nitrogen pool of $U$. lactuca being more than twice that of $F$. vesiculosus, an analogous finding to that for ammonium pools in this study. The variation in storage capacity is thus believed to be due primarily to a 6 -fold greater growth rate in $U$. lactuca (Pedersen \& Borum 1996). The low growth rates of persistent, low SA:V ratio species may therefore give these plants an increased ability to buffer nutrient variability (Ramus \& Venable 1987, Carpenter 1990).

\section{Carbon metabolism in New Zealand seaweeds}

In agreement with previous studies (e.g. Enríquez et al. 1995, 1996), maximum mass-specific rates of photosynthesis related strongly to thallus morphology, and the rate of photosynthesis varied relatively little when expressed per unit area, reflecting the surface-related nature of photosynthesis. With the exception of Enteromorpha sp., rates of respiration also varied little when normalised to surface area. This is somewhat counterintuitive given that respiration occurs in all living cells and, thus, should relate more strongly to plant biomass than does photosynthesis. Differences in maximum photosynthetic and dark respiration rates between New Zealand and northern hemisphere seaweeds (present study) were minor compared with differences in ammonium uptake between the 2 regions (Taylor et al. 1998). This suggests that whatever factor(s) is responsible for the major differences in ammonium uptake has little or no influence on carbon metabolism.

\section{Relationship between the rate of internally controlled ammonium uptake $\left(V_{\mathrm{i}}\right)$ and the maximum rate of ammonium assimilation}

There is strong evidence that $V_{1}$ rate of ammonium uptake does represent the maximum rate of ammonium assimilation in seaweeds. In the green seaweed Ulva sp., the red seaweed Osmundaria colensoi, and the brown seaweed Zonaria turneriana, $V_{1}$ was very similar to the calculated assimilation rate during $V_{s}$ Moreover, in the green seaweed, Enteromorpha sp. uptake during $V_{\mathrm{i}}$ matches the assimilation rate during both $V_{\mathrm{i}}$ and $V_{\mathrm{s}}$ (Rees et al. 1998). It should be noted that determination of the maximum rate of assimilation using the CCCP method is laborious with red and brown algae, because of the use of Conway microdiffusion dishes, and that the method does not work with some red algae (e.g. Pterocladia capillacea) (our unpubl. dataj. Consequently, the easiest way to determine the maximum rate of ammonium assimilation in seaweeds is to measure $V_{1}$.

Acknowledgements. Financial support was provided to T.A.V.R. from the University of Auckland Research Cormmittee and University Grants Committee of New Zealand. We are grateful to $B$. Dobson for nutrient analyses and to the 4 anonymous reviewers for greatly improving the manuscript.

\section{LITERATURE CITED}

Bidwell RGS, McLachlan J (1985) Carbon nutrition of seaweeds: photosynthesis, photorespiration and respiration. J Exp Mar Biol Ecol 86:15-46

Carpenter RC (1990) Competition among marine macroalgae a physiological perspective. J Phycol 26:6-12

Conway HL, Harrison PJ, Davis CO (1976) Marine diatoms grown in chemostats under silicate or ammonium limitation. II. Transient response of Skeletonema costatum to a single addition of the limiting nutrient. Mar Biol 35 : $187-199$

Enri.quez S, Duarte CM, Sand-Jensen K (1995) Patterns in the photosynthetic metabolism of Mediterranean macrophytes. Mar Ecol Prog Ser 119:243-252

Enriquez S, Duarte CM, Sand-Jensen K, Nielsen SL (1996) Broad-scale comparison of photosynthetic rates across photosynthetic organisms. Oecologia 108:197-206

Fujita RM (1985) The role of nitrogen status in regulating transient ammonium uptake and nitrogen storage by macroalgae. J Exp Mar Biol. Ecol 92:283-301 
Hanisak MD (1983) The nitrogen relationships of marine macroalgae. In: Carpenter EJ, Capone DG (eds) Nitrogen in the marine environment. Academic Press, New York, p $699-730$

Harrison PJ, Druehl LD (1982) Nutrient uptake and growth in the Laminariales and other macrophytes: a consideration of methods. In: Srivastava LM (ed) Synthetic and degradative processes in marine macrophytes. Walter de Gruyter, Berlin, p 99-120

Harrison PJ, Parslow JS, Conway HL (1989) Determination of nutrient uptake kinetic parameters: a comparison of methods. Mar Ecol Prog Ser 52:301-312

Harvey PH, Pagel MD (1991) The comparative method in evolutionary biology. Oxford University Press, Oxford

Hein M, Pedersen MF, Sand-Jensen K (1995) Size-dependent nitrogen uptake in micro- and macroalgae. Mar Ecol Prog Ser 118:247-253

Koroleff F (1983) Determination of ammonia. In: Grasshoff K, Ehrhardt M, Kremling K (eds) Methods of seawater analy5is. Verlag Chemie, Weinheim, p 150-157

Kremer BP (1980) Transversal profiles of carbon assimilation in the fronds of three Laminaria species. Mar Biol 59: 95-103

LaBarbera M (1989) Analyzing body size as a factor in ecology and evolution. Annu Rev Ecol Syst 20:97-117

Lea PJ, Robinson SA, Stewart GR (1990) The enzymology and metabolism of glutamine, glutamate, and asparagine. In: Miflin BJ, Lea PJ (eds) The biochemistry of plants: a comprehensive treatise. Vol 16: Intermediary nitrogen metabolism. Academic Press, San Diego, p 121-159

Littler MM, Littler DS (1980) The evolution of thallus form and survival strategies in benthic marine macroalgae: field and laboratory tests of a functional form model. Am Nat $116: 25-44$

Lobban CS, Harrison PJ (1994) Seaweed ecology and physiology. Cambridge University Press, Cambridge

Markager S, Sand-Jensen K (1994) The physiology and ecology of light-growth relationship in macroalgae. Prog Phycol Res 10:209-298

McGlathery KJ, Pedersen MF, Borum J (1996) Changes in intracellular nitrogen pools and feedback controls on nitrogen uptake in Chaetomorpha linum (Chlorophyta). J Phycol 32:393-401

Nielsen SL, Sand-Jensen K (1990) Allometric scaling of maximal photosynthetic growth rate to surface/volume ratio. Limnol Oceanogr 35:177-181

Oliveira IC, Lam HM, Coschigano K, Melo-Oliveira R, Coruzzi G (1997) Molecular-genetic dissection of ammonium assimilation in Arabidopsis thaliana. Plant Physiol Biochem 35:185-198

Pedersen MF (1994) Transient ammonium uptake in the macroalga Ulva lactuca (Chlorophyta): nature, regulation, and the consequences for choice of measuring technique. J Phycol 30:980-986

Pedersen MF, Borum J (1996) Nutrient control of algal growth in estuarine waters. Nutrient limitation and the importance of nitrogen requirements and nitrogen storage

Editorial responsibility: Otto Kinne (Editor),

Oldendorf/Luhe, Germany among phytoplankton and species of macroalgae. Mar Ecol Prog Ser 142:261-272

Pedersen MF, Borum J (1997) Nutrient control of estuarine macroalgae: growth strategy and the balance between nitrogen requirements and uptake. Mar Ecol Prog Ser 161: $155-163$

Ramus J (1978) Seaweed anatomy and photosynthetic performance: the ecological significance of light guides, heterogenous absorption and multiple scatter J Phycol 14: $352-362$

Ramus J, Venable $M$ (1987) Temporal ammonium patchiness and growth rate in Codium and Ulva (Ulvophyceae). J Phycol 23:518-523

Rees TAV, Grant CM, Harmens HE, Taylor RB (1998) Measuring rates of ammonium assimilation in marine algae; use of the protonophore carbonyl cyanide m-chlorophenylhydrazone to distinguish between uptake and assimilation. J Phycol 34:264-272

Ricker WE (1973) Linear regressions in fishery research. J Fish Res Board Can 30:409-434

Riley JP, Skirrow G (1975) Chemical oceanography, Vol 2. 2nd edn. Academic Press, London

Rosenberg G, Ramus J (1984) Uptake of inorganic nitrogen and seaweed surface area. volume ratios. Aquat Bot 19: $65-72$

Rosenberg G, Littler DS, Littler MM, Oliveira EC (1995) Primary production and photosynthetic quotients of seaweeds from Sào Paulo State, Brazil. Bot Mar 38:369-377

Slawyk G, Coste B, Collos Y, Rodier M (1997) Isotopic and enzymatic analyses of planktonic nitrogen utilisation in the vicinity of Cape Sines (Portugal) during weak upwelling activity. Deep-Sea Res 44:1-25

Sokal RR, Rohlf FJ (1981) Biometry, 2nd edn. WH Freeman and $\mathrm{Co}, \mathrm{New}$ York

Syrett PJ (1953) The assimilation of ammonia by nitrogenstarved cells of Chlorella vulgaris. Part II. The assimilation of ammonia to other compounds. Ann Bot 17:21-36

Syrett PJ (1981) Nitrogen metabolism of microalgae. In: Platt $T$ (ed) Physiological bases of phytoplankton ecology. Can Bull Fish Aquat Sci 210:182-209

Taylor RB, Peek JTA, Rees TAV (1998) Scaling of ammonium uptake by seaweeds to surface area:volume ratio:geographical variation and the role of uptake by passive diffusion. Mar Ecol Prog Ser 169:143-148

Turpin DH (1991) Effects of inorganic $\mathrm{N}$ availability on algal photosynthesis and carbon metabolism. J Phycol 27:14-20

Turpin DH, Elrifi IR, Birch DG, Weger HG, Holmes JJ (1988) Interactions between photosynthesis, respiration, and nitrogen assimilation in microalgae, Can $J$ Bot 66 $2083-2097$

Vergara JJ, Bird KT, Niell FX (1995) Nitrogen assimilation following $\mathrm{NH}_{4}{ }^{+}$pulses in the red alga Gracilariopsis lemaneiformis: effect on C metabolism. Mar Ecol Prog Ser 122:253-263

Vergara JJ, Niell FX, Bird KT (1997) A dynamic model of transient $\mathrm{NH}_{4}{ }^{+}$assimilation in red algae. Mar Ecol Prog Ser 148:295-307

Submitted: October 20, 1998, Accepted: March 19, 1999

Proofs received from author(s): July 8, 1999 